\title{
U potrazi za egalitarnim sindromom: kulturalna inercija u Hrvatskoj?
}

Burić, Ivan; Štulhofer, Aleksandar

Source / Izvornik: Odabrani prijevodi, 2016, 7, 1 - 20

Journal article, Published version

Rad u časopisu, Objavljena verzija rada (izdavačev PDF)

https://doi.org/10.3326/op.43

Permanent link / Trajna poveznica: https:/urn.nsk.hr/urn:nbn:hr:242:335423

Rights / Prava: Attribution-NonCommercial-NoDerivatives 4.0 International/ImenovanjeNekomercijalno-Bez prerada 4.0 međunarodna

Download date / Datum preuzimanja: 2023-04-26

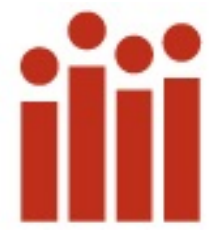

Repository / Repozitorij:

Institute of Public Finance Repository

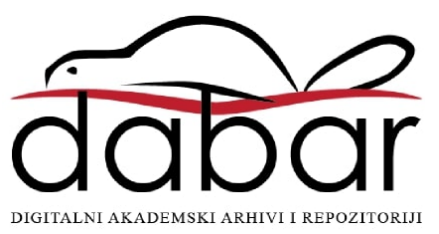


Institut za

javne financije

Smičiklasova 21 | Zagreb

www.ijf.hr | ured@ijf.hr

T: 01/4886-444 | F: 01/4819-365

\section{ODABRANI}

\section{PRIJEVODI}

\section{BR. 43}

\section{6.}

ISSN 1847-7445

citirati: Burić, I. i Štulhofer, A., 2016. In search of the egalitarian syndrome: cultural inertia in Croatia?. Financial Theory and Practice, 40 (4), str. 361-382. Dostupno na: <http://www.fintp.hr/upload/files/ftp/2016/4/buric_stulhofer. $\mathrm{pdf}>$.

Svi Odabrani prijevodi dostupni su na: http://www.ijf.hr/hr/publikacije/casopi si/12/odabrani-prijevodi/111/

\section{U POTRAZI ZA EGALITARNIM SINDROMOM: KULTURALNA INERCIJA U HRVATSKOJ?}

\author{
DR. SC. IVAN BURIĆ \\ DR. SC. ALEKSANDAR ŠTULHOFER*
}

ČLANAK ${ }^{* *}$

JEL: Z13

DOI: $10.3326 /$ op. 43

\section{SAŽETAK}

Nastojeći rastumačiti kulturalne prepreke modernizaciji zemlje, Josip Županov je 1970. godine izložio teoriju egalitarnog sindroma (TES). Nedavna operacionalizacija TES-a" (Štulhofer i Burić, 2015.) po prvi je put omogućila testiranje hipoteze o perzistenciji tog specifičnog kulturalnog obrasca, ali i analizu pretpostavljene (negativne) povezanosti $s$ društvenim razvojem. Koristeći nacionalni probabilistički uzorak, u ovome radu predstavljamo dodatnu validaciju složene mjere egalitarnog sindroma te nalaze vezane uz perzistenciju egalitarnog sindroma i njegovu povezanost s indikatorima županijske razvijenosti. Dobiveni rezultati govore u prilog Županovljevim teorijskim očekivanjima. Strukturalna i socioekonomska obilježja (veličina prebivališta, obrazovanje i profesionalni status), a ne dob sudionika, pokazali su se značajnim prediktorima prihvaćanja vrijednosnog sklopa koji Županov opisuje kao "radikalni egalitarizam". Prihvaćanje tih vrijednosti pokazalo se značajno (i negativno) povezano sa stupnjem županijske razvijenosti, konkurentnosti i rane poduzetničke aktivnosti. Premda smjer kauzalnosti u odnosu između egalitarnog sindroma i društvenog razvoja ostaje otvoreno pitanje, utvrđena raširenost vrijednosti koje čine egalitarni sindrom - osobito antipoduzetnički sentiment i sklonost državnom paternalizmu - potencijalni je problem za buduće socioekonomske reforme.

Ključne riječi: egalitarni sindrom, Županov, validacija, kulturalna inercija, razvijenost županija

\footnotetext{
* Autori zahvaljuju agenciji Ipsos na podacima koji su omogućili ovaj rad. Zahvaljujemo, također, Velimiru Šonji, Željku Ivankoviću, Danijeli Dolenec, Vojmiru Franičeviću i drugim sudionicima dva okrugla stola održana u Zagrebu, u travnju 2016., na Ekonomskom institutu te Matici hrvatskoj. Osobitu zahvalnost dugujemo kolegicama Slavici Singer i Nataši Šarliji, koje su nam stavile na raspolaganje županijske vrijednosti TEA indikatora u dvije točke mjerenja (2014. i 2015.), te anonimnim recenzentima časopisa, čije su primjedbe i kritičke sugestije pomogle otkloniti barem dio nedostataka u ovome radu.

${ }^{* *}$ Primljeno: 1. lipnja 2016.

Prihvaćeno: 5. listopada 2016.
}

Članak je osvojio nagradu u kategoriji redovitih radova zaklade Prof. dr. Marijan Hanžeković za 2016. godinu.

Ivan BURIĆ

Odjel za komunikologiju, Hrvatski studiji, Sveučilište u Zagrebu, Borongajska cesta 83d, 10000 Zagreb

e-mail: iburic@hrstud.hr

Aleksandar ŠTULHOFER

Odsjek za sociologiju, Filozofski fakultet, Sveučilište u Zagrebu, Ivana Lučića 3, 10000 Zagreb

e-mail: astulhof@ffzg.hr 
Vrijednosti su fenomen dugog trajanja: polako nastaju, ali i vrlo polako nestaju.

(Županov, 1993.:192)

\section{UvoD}

Čini se da hrvatski sociolozi dijele stav o tome da je teorija egalitarnog sindroma (TES) Josipa Županova najznačajniji teorijski koncept razvijen u domaćoj sociologiji (Fanuko, 2011.; Lalić, 2005.; Sekulić i Šporer, 2005.). Županov je TES razvio krajem šezdesetih godina prošlog stoljeća, a zatim ju je kroz idućih trideset godina sustavno koristio u svojim analizama jugoslavenskog, a potom i hrvatskog društva. ${ }^{1}$ Teorija se zasniva na tezi da jugoslavensko društvo s kraja dvadesetog stoljeća, kao i hrvatsko društvo s početka novog milenija, baštini specifičan socio-kulturni obrazac predmodernih seljačkih društava, koja priječi efikasan društveno gospodarski razvoj. Taj obrazac Županov naziva egalitarnim sindromom i konceptualizira ga kao "klaster kognitivnih perspektiva, etičkih zasada, društvenih normi i kolektivnih stavova" (Županov, 1977.:46).

Spomenuti klaster sastoji se od sedam dimenzija, odnosno sedam različitih manifestacija egalitarnih stavova, vrijednosti ili perspektiva (Županov, 1970.). Prvu dimenziju ili komponentu egalitarnog sindroma Županov naziva perspektivom ograničenog dobra. Ona predstavlja kognitivnu komponentu egalitarnog sindroma jer usmjerava nacionalnu politiku prema egalitarnoj raspodjeli društvenog bogatstva. Druga dimenzija je redistributivna etika, a proizlazi iz moralne obveze svojstvene predindustrijskim društvima koja nalaže (pre)raspodjelu bogatstva kako bi društvene razlike bile što manje. Treća dimenzija je norma egalitarne raspodjele. Radi se o uspostavljanju granične vrijednosti iznad koje porast nominalne zarade više nije dopustiv, bez obzira na sposobnosti i ostale okolnosti. Četvrta dimenzija egalitarnog sindroma jest opsesija o privatniku. Izražava se u negativnom stavu prema privatnom poduzetništvu, a sastoji se od tri poddimenzije: fobije bogaćenja, državno-vlasničkog kompleksa i antipoduzetničkog mentaliteta. Peta dimenzija egalitarnog sindroma je antiprofesionalizam. On podrazumijeva negativan stav prema profesionalnom znanju i autonomnim profesionalnim normama. Šestu dimenziju egalitarnog sindroma Županov naziva intelektualnom uravnilovkom, a vezuje je uz antipoduzetništvo, antiinovativnost $i$ antikreativnost. Posljednja, sedma dimenzija egalitarnog sindroma jest antiintektualizam, to jest negativan stav prema intelektualnom radu kao takvom (Županov, 1970.; 1977.; 1983.).

Županov je smatrao kako sinteza navedenih dimenzija djeluje kao čimbenik kulturne inercije koja je u jugoslavenskom društvu usporavala i/ili smanjivala doseg modernizacijskih promjena, da bi kasnije, u postsocijalističkom hrvatskom društvu, bila odgovorna za niz tranzicijskih problema i devijacija u socioekonomskom razvoju.

Prihvaćajući Županovljevu teoriju kao teoriju srednjeg dometa, ali i potaknuti kritikom kako je Županov propustio empirijski verificirati svoj model (usp. Dolenec, 2014.), u prethodnom smo

\footnotetext{
1 Osnovne propozicije TES-a Županov je prvi put sustavno prezentirao u tekstu Egalitarizam $i$ industrijalizam, objavljenom u časopisu "Naše teme" (Županov, 1970.). Nakon toga teoriju je intenzivno koristio tijekom čitave svoje znanstvene karijere. Vidjeti npr. Sociologija i samoupravljanje (1977.), Marginalije o društvenoj krizi (1983.), Poslije potopa (1995.), Od komunističkog pakla do divljeg kapitalizma (2002.).
} 
radu predstavili operacionalizaciju TES-a i ponudili dvije verzije kompozitnog indikatora egalitarnog sindroma (Štulhofer i Burić, 2015.).2

Rezultati tog istraživanja, provedenog na studentskom uzorku, potvrdili su mogućnost operacionalizacije egalitarnog sindroma kao latentnog konstrukta višeg reda. Testiranje je pokazalo kako je originalnu Županovljevu konceptualizaciju, koja obuhvaća sedam dimenzija, potrebno reducirati na pet dimenzija ${ }^{3}$ od kojih jedna (intelektualni egalitarizam) uključuje tri originalne dimenzije - kako bi se postiglo dobro pristajanje podacima (Štulhofer i Burić, 2015.).

Namjera autora da ponude valjani mjerni instrument koji bi mogao poslužiti u širokom rasponu društvenih istraživanja rezultirala je imperativom provođenja novog istraživanja. Njime smo željeli dodatno provjeriti valjanost dviju konstruiranih skala egalitarnog sindroma (SEMA-27 i SEMA-15), ovoga puta na uzorku opće populacije, ali i barem djelomično provjeriti Županovljevu tvrdnju o perzistenciji i efektima egalitarnog sindroma u suvremenom hrvatskom društvu.

Kao što je poznato, niti nakon promjene društveno-političkog uređenja Županov nije odustajao od svoje teorije, već ju je koristio za analizu sociokulturne pozadine devijantnih efekata tranzicijskih procesa (Županov, 1995.; 2002.). Nekoliko njegovih tadašnjih uvida čini se relevantnim i za današnju situaciju. Takav je, primjerice, slučaj s koncepcijom političkog kapitalizma (Županov, 2002). Ovim konceptom Županov apostrofira neke od značajnijih tranzicijskih aberacija, poput povezanosti političkih i ekonomskih elita (politički klijentelizam) te politički motiviranog državnog paternalizma koji rezultira prevelikim udjelom države u BDP-u4. Pojedine propozicije političkog kapitalizma, kako ga vidi Županov, u velikoj se mjeri odnose na neke od ključnih problema s kojima se trenutno suočava hrvatsko društvo. Stoga, ukoliko taj koncept barem donekle objašnjava pojedine tranzicijske ishode, tada $\mathrm{u}$ njemu vjerojatno možemo pronaći pozadinu za problematiziranje fenomena kao što su (ne)racionalnost teritorijalnog ustroja, korupcija i "uhljebljivanje" stranačkih kolega, hipertrofija državnih institucija i agencija, prevelika ovisnost građana o državnim transferima, pretjerana državna potrošnja, rast javnog duga i tako dalje. U tom smislu, bilo bi važno ispitati može li TES pružiti teorijsko uporište za analizu spomenutih oblika društvene disfunkcionalnosti.

Još je nekoliko istaknutih mjesta Županovljevog bavljenja tranzicijskim problemima koja otvaraju mogućnost posttranzicijske refleksije na TES, zbog kojih smatramo da Županovljev teorijski model zavrjeđuje daljnju znanstvenu, prvenstveno empirijsku, reaktualizaciju. Primjerice, Županov se bavio i temom fleksibilnosti rada te odnosom građana Hrvatske prema EU i njenim vrednotama (v. Županov, 2002.). Prijepori o potrebi fleksibilizacije tržišta rada te odgovarajućim promjenama radnog zakonodavstva već su nekoliko godina sastavni dio brojnih rasprava i analiza o poželjnim smjerovima društvenog razvoja ${ }^{5}$. Ostavimo li po strani dvojbu je li opisana reforma tržišta rada nužna, županovljevski relevantno istraživačko pitanje glasilo bi u kojoj se mjeri postojeći

\footnotetext{
${ }^{2}$ U radu smo ponudili dužu (27 čestica) i kraću (15 čestica) verziju skale egalitarnog sindroma (SEMA), mjernog instrumenta pogodnog za uporabu u širokom rasponu društvenih istraživanja.

${ }^{3}$ Riječ je o perspektivi ograničenog dobra, redistributivnoj etici, egalitarnoj raspodjeli, opsesiji o privatniku te intelektualnom egalitarizmu.

${ }^{4} \mathrm{~S}$ obzirom na tematiku i ton brojnih rasprava o dominantnim hrvatskim ekonomskim problemima, čini se da je Županovljeva tvrdnja iz 1983. da je u "našim privrednim organizacijama ugrađena orijentacija prema državi" još uvijek aktualna (Županov, 1983.:66).

5 Prisjetimo se samo količine rasprava koju je, kako u javnosti tako i u stručnim krugovima, 2014. godine potaknula vladina inicijativa za uvođenje tzv. outsourcinga u državne institucije.
} 
sociokulturni kontekst pojavljuje kao prepreka prilagodbi lokalnoj i globalnoj dinamici tržišta rada i radnih odnosa.

Izuzetno zanimljivo bilo bi i provjeriti Županovljevu tezu kako gospodarska kriza radikalizira egalitarizam (Županov, 1983.:60). ${ }^{6}$ U vrijeme nastanka ovoga rada, čini se kako Hrvatska počinje izlaziti iz višegodišnje krize koja se manifestirala pogoršanjem većine društvenih pokazatelja, ali i produbljivanjem društvenih nejednakosti ${ }^{7}$. Odražava li se djelovanje društvene krize, porast socijalnih nejednakosti i visoka razina društvene otvorenosti - pospješena članstvom u EU - u jačanju egalitarističkih vrijednosti? Odgovor na ovo pitanje, kao i u slučaju problematike fleksibilizacije tržišta rada, usko je povezan s temeljnom propozicijom TES-a prema kojoj vrijednosni sustavi mogu djelovati kao prepreke ili pokretači društvenog razvoja. Postoje, dakle, brojna mjesta u suvremenom društvenom i ekonomskom trenutku Hrvatske koja je moguće povezati sa Županovljevom konceptualizacijom.

Pristupajući Županovljevom paradigmatskom polazištu u razmatranju društvenog razvoja na način na koji Swindlerova (1986.) tumači kulturu - kao kutiji alata za individualne i kolektivne akcije ${ }^{8}$ ovim bismo radom željeli potaknuti interes za uključivanjem kulturalnih varijabli u domaća socioekonomska istraživanja. Pritom ne mislimo isključivo na analizu kulturalnih obrazaca koji su, barem za Županova, krivi za naše razvojne neuspjehe, već i na suprotnu mogućnost, to jest angažiranje domaćih društvenih znanstvenika na analizi kulturalnih obrazaca zaslužnih za razvojne uspjehe.

\footnotetext{
${ }^{6}$ Dolenec kritizira Županovljevu teoriju kao napad na društvenu solidarnost i jednakost (Dolenec, 2014.), no teorija egalitarnog sindroma nije (opća) teorija egalitarizma, pa time niti kritika ideje egalitarnosti. Važno je uočiti kako je u radu u kojem je po prvi put predstavio TES Županov jasno razlučio "egalitarizam položaja”, odnosno šansi (jednaki start u natjecanju za društvene položaje), od "egalitarizma nagrada" (Županov, 1970.:33), smatrajući kako je upravo druga koncepcija težišna točka egalitarnog sindroma. No, to ne znači da Županov egalitarizam položaja smatra idealnim rješenjem. Ukazujući na njegovu inherentnu konzervativnost jer siromaštvo nerijetko interpretira kao osobni promašaj (Županov, 1970.; str. 35-37), ipak ga smatra stabilizacijskim čimbenikom - za razliku od egalitarizma nagrada koji smatra radikalnim i teorijski konfliktnim (str. 34). Egalitarni sindrom za Županova je, dakle, "radikalni egalitarizam" (Županov, 1993.) usporediv sa Scanlonovim tumačenjem supstancijalnog egalitarizma koji pretpostavlja jednakost "života i sudbina" (Scanlon, 1997.:1), odnosno Frankfurtovim tumačenjem ekonomskog egalitarianizma kao "doktrine prema kojoj je poželjno da svatko posjeduje podjednaku količinu novca i bogatstva" (Frankfurt, 2015:6).

Premda se nije bavio normativnim, jer je odbacivao ideju angažirane (preskriptivne) sociologije, Županov je bio iznimno osjetljiv na društvene nejednakosti - poglavito kada je riječ o nejednakostima koje su nastajale i rasle 1990.-tih godina (Županov, 1995.; 2002.; 2011.). Moguće je, naravno, prigovoriti kako je shvaćanje egalitarnosti u suvremenoj moralnoj filozofiji daleko odmaklo od jednostavne dihotomije koju Županov koristi. Primjerice, konceptualizacije egalitarnosti u radovima Rawlsa (1971.), Scanlona (1997.), Walzera (1983.), Sena (1992.) ili Dworkina (1981a.; 1981b.) se u mnogome razlikuju. No, upravo taj pluralizam ideja o egalitarnosti te, slijedom toga, argumentacija moralne neodrživosti društvenih nejednakosti upućuju na pogrešnost zaključka da se TES obračunava sa samom idejom egalitarnosti. Egalitarizmi, kao i ruže, mirišu različito. Ili, ponekad, nemaju mirisa.

Pluralizam konceptualizacija egalitarnosti vodi pitanju što zapravo mjeri SEMA? Pitanje je na prvi pogled trivijalno jer, metodološki promatrano, instrument mjeri skup ili kombinaciju pet dimenzija prikazinih na slikama 1 i 2 . No, u praktičnom smislu - razmišljajući, dakle, o mogućim društvenim posljedicama egalitarnog sindroma - pitanje je itekako relevantno. Uzimajući u obzir unutarnju i vanjsku valjanost poddimenzija SEMA, težišne bi vrijednosti egalitarnog sindroma trebalo ponajprije tražiti u normi egalitarne raspodjele te antipoduzetničkim stavovima.

7 Prema podacima Hrvatskog statističkog zavoda, 2007. vrijednost Gini koeficijenta nejednakosti dohotka bila je 0,28, a relativni jaz rizika od siromaštva iznosio je 24,9\%. Na kraju krize, 2014., Gini koeficijent se povećao na 0,302, a relativni jaz rizika siromaštva na 27,9\% (usp. http://www.dzs.hr/Hrv_Eng/publication/2015/14-01-01_01_2015.htm i http://www.dzs.hr/hrv/publication/2009/14-1-2_1h2009.htm).

${ }^{8} \mathrm{Na}$ to, čini se, ukazuje i Fanuko kada navodi da je u svojim kasnijim radovima Županov dao naslutiti svoju privrženost jednoj općenitijoj sociološkoj paradigmi. Fanuko ističe da Županov "napušta relativno čvrst okvir industrijske sociologije i kreće u avanturu analize globalnoga društvenog sistema sa stajališta kulturne sociologije. Prema vlastitom priznanju, on napušta marksističku analizu koja naglašava promjenu i društveni konflikt u korist teoretiziranja o društvu zasnovanog na kontinuitetu kulturne tradicije" (Fanuko, 2011.:132).
} 


\subsection{CiLJEVI STUDIJE I HIPOTEZE}

Ovaj rad ima dva međusobno povezana cilja. Kao što smo već spomenuli, prvi cilj je dodatna provjera složenog instrumenta koji mjeri egalitarni sindrom. Nastavljajući proces validacije započet u prethodnom radu (usp. Štulhofer i Burić, 2015.), ovdje koristimo probabilistički uzorak opće populacije kako bismo ispitali valjanost konfirmacijskog modela egalitarnog sindroma, koji je razrađen i inicijalno potvrđen na studentskom uzorku. Također, analiziramo i invarijantnost modela u odnosu na spol i dob sudionika. ${ }^{9}$

Drugi cilj istraživanja odnosi se na analizu moguće perzistencije egalitarnog sindroma u suvremenom hrvatskom društvu. Polazeći od Županovljevih teza o "trajanju", odnosno sociokulturnoj otpornosti, egalitarnog sindroma i u postsocijalističkom razdoblju (Županov, 1993.; 2011.) u radu testiramo sljedeće dvije hipoteze: hipotezu o kulturnoj inerciji ili perzistenciji egalitarnog sindroma te hipotezu o mogućim posljedicama kulturne inercije.

Kulturnu inerciju, odnosno perzistiranje naslijeđenih kulturalnih obrazaca (vrijednosti, norme, kolektivne navike i slično), možemo definirati kao njihov dugotrajni utjecaj (Zarate, Shaw, Marquez i Biagas, 2012.). Takva otpornost na promjene može biti kontraproduktivna jer su naslijeđeni kulturalni alati nerijetko suboptimalni u novim okolnostima. Županov je tako sklop vrijednosti koje je nazvao egalitarnim sindromom eksplicitno smatrao čimbenikom kulturne inercije, odnosno preprekom za društveni razvoj. U tom smislu, empirijska reaktualizacija TES-a nužno uključuje razmatranje pitanja o efektima egalitarnog sindroma, na način na koji ih je Županov konceptualizirao

Hipoteza o kulturalnoj inerciji ili perzistenciji egalitarnog sindroma. S obzirom na nedostupnost longitudinalnih podataka, hipotezu je moguće testirati na način da se ispitanici različite dobi tretiraju kao različite dobne kohorte. Pozitivna povezanost dobi i vrijednosti na skali egalitarnog sindroma ukazivala bi na postojanje kulturalne inercije. S obzirom da su se obrazovna i dohodovna struktura populacije značajno promijenile od 1970., testiranje veze između dobi i prihvaćanja egalitarnog sindroma pretpostavlja kontrolu tih obilježja koja bi mogla zamagliti generacijske razlike. Za pretpostaviti je, također, kako će prihvaćanje egalitarnog sindroma biti izraženije među sudionicima nižeg socioekonomskog statusa - s obzirom na veću osobnu korist od prihvaćanja egalitarnih normi.

Hipoteza o mogućim posljedicama kulturalne inercije. U skladu sa Županovljevim razumijevanjem negativnih posljedica egalitarnog sindroma (prihvaćanje egalitarizma otežava socioekonomski razvoj), očekujemo negativnu povezanosti između indikatora županijske razvijenosti i prosječnog prihvaćanja egalitarnog sindroma na županijskoj razini.

\section{Metoda ISTRAŽIVANJA}

\subsection{UZORAK I PROCEDURA}

Istraživanje na kojem se temelji ovaj rad provedeno je na nacionalnom probabilističkom uzorku veličine 1.000 ispitanika u dobi između 15 i 88 godina, u sklopu standardnog mjesečnog omnibus ispitivanja agencije za istraživanje tržišta i javnog mnijenja Ipsos. Korišteno je dvoetapno

\footnotetext{
${ }^{9}$ Ovdje valja uočiti kako bez potvrde invarijantnosti modela egalitarnog sindroma drugi cilj nije dohvatljiv. Bez potvrde da razvijeni instrument podjednako dobro mjeri isti fenomen (egalitarni sindrom) u različitim dobnim skupinama, testiranje hipoteze o kulturalnoj perzistenciji nije izvedivo.
} 
stratificirano uzorkovanje. U prvom koraku, stratifikacija je obavljena prema regionalnom kriteriju na način da je definirano šest tradicionalnih regija koje su određene kao skup županija ${ }^{10}$. U drugom koraku, stratifikacija je obavljena prema kriteriju veličine naselja11. Pri izboru naselja u kojima je obavljeno istraživanje, kao primarnih jedinica izbora, unutar svakog stratuma korištena je metoda vjerojatnosti proporcionalne veličini, što znači da je vjerojatnost izbora jedinice (pojedino naselje) odgovarala njezinoj veličini (broj stanovnika u dobi od 15 i više godina). Izbor kućanstava, kao sekundarnih jedinica izbora, unutar odabranih naselja temeljio se na slučajnom izboru adresa kao polaznih točaka (random starting points metoda) te standardiziranom procedurom izbora kućanstava u odnosu na polaznu točku (random walk metoda).

U cilju postizanja optimalne razine reprezentativnosti uzorka po najvažnijim sociodemografskim obilježjima, prije procesa obrade podataka izvršeno je njihovo ponderiranje. Korišteni su ponderi konstruirani s obzirom na dob, obrazovanje te broj stanovnika u urbanim i ruralnim krajevima. S obzirom na način uzorkovanja, ali i veličinu županijskih poduzoraka ${ }^{12}$, rezultati analiza mogu se smatrati reprezentativnim za populaciju na nacionalnoj, no ne i županijskoj razini.

Shodno populacijskom omjeru, u ukupnom je uzorku nešto više žena (52\%). Najveći broj sudionika istraživanja (44\%) bio je stariji od 50 godina. Otprilike jedna trećina njih (32\%) bila je u dobi između 30 i 50 godina, a $24 \%$ ih je bilo mlađe od 30 godina. S obzirom na obrazovanje, prevladavali su sudionici sa završenom srednjom školom/gimnazijom (54\%). Nešto manje od jedne trećine (30\%) imalo je potpuno ili nepotpuno osnovno obrazovanje, a 17\% višu školu ili fakultet. Najveći broj sudionika istraživanja živio je u Zagrebu i okolici (26\%) te Dalmaciji (20\%). Najmanji broj sudionika istraživanja živio je na području Like i Banovine (9\%). Relativna većina anketiranih (39\%) živjela je u naseljima veličine do 2.000 stanovnika, odnosno u naseljima od 2.000-10.000 stanovnika (35\%). U gradskim je naseljima bilo smješteno 64\% sudionika istraživanja.

\subsection{INSTRUMENTI}

Temeljem operacionalizacije i niza statističkih analiza prikazanih u našem ranijem radu (usp. prilog u Štulhofer i Burić, 2015.), mjerenje egalitarnog sindroma uključilo je 27 čestica koje pokrivaju svih sedam originalnih dimenzija (Županov, 1970.).

Za ispitivanje konvergencijske valjanosti dviju verzija Skale egalitarnog sindroma (duže od 27 i kraće od 15 čestica) koristili smo složeni indikator averzije spram rizika (Carter i Yeqing, 2005.), čija je pouzdanost u ovoj studiji bila zadovoljavajuća (Cronbachov $\alpha=0,83$ ).

U postupku testiranja hipoteze o kulturnoj inerciji, uz skalu SEMA-27 koristili smo sljedeće sociodemografske indikatore: spol, dob, mjesto stanovanja (ruralno, naselja do 2.000 stanovnika, u odnosu na urbano, naselja s više od 2.000 stanovnika), zanimanje ${ }^{13}$, stupanj obrazovanja (u

\footnotetext{
10 Definirane su sljedeće regije: Zagreb i okolica (Grad Zagreb i Zagrebačka županija), Sjeverna Hrvatska (Krapinskozagorska, Varaždinska, Koprivničko-križevačka, Bjelovarsko-bilogorska, Virovitičko-podravska, Međimurska županija), Slavonija (Požeško-slavonska, Brodsko-posavska, Osječko-baranjska, Vukovarsko-srijemska županija), Lika i Banovina (Sisačko-moslavačka, Karlovačka, Ličko-senjska županija), Istra, Hrvatsko primorje i Gorski kotar (Istarska, Primorskogoranska županija), Dalmacija (Zadarsko-kninska, Šibenska, Splitsko-dalmatinska, Dubrovačko-neretvanska županija).

11 Temeljem ovog kriterija konstruirana su sljedeća četiri stratuma: naselja veličine do 2.000 stanovnika, 2.001-10.000 stanovnika, 10.001 - 100.000 stanovnika i više od 100.000 stanovnika.

12 Veličina županijskih poduzoraka varirala je od 18 (Ličko-senjska županija) do 182 sudionika (Grad Zagreb). Prosječna veličina uzorka na županijskoj razini iznosila je 30 sudionika (SD = 15,1).

13 Varijablu zanimanje činilo je sljedećih osam kategorija: 1 - slobodna profesija (odvjetnici koji imaju kancelariju, zubari i liječnici s privatnom praksom, slobodni umjetnici i glumci itd.), 2 - stručnjaci i intelektualci (profesori, inženjeri, liječnici u državnim ustanovama, itd.), 3 - viši menedžment, viši rukovoditelji, direktori (bilo u vlastitom ili tuđem
} 
rasponu od "bez škole" do "magisterij ili doktorat") te visina osobnih prihoda u proteklom mjesecu (od "bez prihoda" do "12.000 kuna ili više"). Zbog nagnutosti i višemodalnosti, indikatori obrazovanja i prihoda transformirani su u kategorijske varijable (obrazovanje je tercilizirano, a osobni prihodi kvartilizirani).

U postupku testiranja hipoteze o posljedicama kulturne inercije, kao indikatore regionalne razvijenosti koristili smo podatke o bruto domaćem proizvodu (BDP) županija, razliku u promjeni županijskog BDP-a u razdoblju 2000.-2013., indeks razvijenosti te regionalni indeks konkurentnosti. Indeks razvijenosti razvilo je Ministarstvo regionalnog razvoja i fondova Europske unije. Riječ je o složenom pokazatelju koji se računa kao ponderirani prosjek nekoliko temeljnih društveno-gospodarskih pokazatelja, s ciljem mjerenja stupnja razvijenosti jedinica lokalne i područne (regionalne) samouprave ${ }^{14}$. Regionalni indeks konkurentnosti Nacionalnog vijeća za konkurentnost zasniva se na konceptualizaciji Svjetskog gospodarskog foruma, koja konkurenciju definira kao skup institucija, politika i faktora koji određuju razinu produktivnosti u nekoj zemlji, ali i na definiciji EU-a, prema kojoj je regionalna konkurentnost sposobnost kreiranja atraktivnog i održivog okruženja za poslovanje i življenje ${ }^{15}$. Podaci indeksa konkurentnosti, izraženi u formi rangova, dostupni su na županijskog razini. Uz opisane indekse, koristili smo i TEA (total earlystage entrepreneurial activity) indikator razvijen u sklopu međunarodnog istraživanja GEM (Global Entrepreneurship Monitor), u kojem od 2002. sudjeluje i Hrvatska (Singer, Šarlija, Pfeifer i Oberman Peterka, 2016.). ${ }^{16}$ TEA mjeri poduzetničku aktivnost poduzetnika početnika (pokrenuli posao prije ne više od tri mjeseca) te novih poduzetnika (isplaćuju plaće više od tri, ali manje od 42 mjeseca), čiji broj prikazuje kao postotak stanovnika u dobi između 18 i 64 godine. Za potrebe ovoga rada, imali smo na raspolaganju županijske vrijednosti TEA u 2014. te 2015. godini.

Za potrebe testiranja hipoteze o mogućim posljedicama kulturne inercije izračunali smo županijsku razinu prihvaćanja egalitarnog sindroma, odnosno prosjek vrijednosti SEMA-27 sudionika istraživanja iz svake pojedine županije.

\subsection{STATISTIČKA ANALIZA}

Višedimenzionalni model egalitarnog sindroma - razvijen u našem prehodnom radu (Štulhofer i Burić, 2015.) - testiran je konfirmacijskom faktorskom analizom višeg reda uz uporabu ML (maximum likelihood) estimatora. Osnovna prednost konfirmacijske analize u odnosu na druge metode jest testiranje unaprijed (teorijski) definiranog modela, pri čemu se pristajanje modela prikupljenim podacima određuje uzimajući u obzir pogrešku mjerenja (Byrne, 2009.; Hair, Black, Babin i Anderson, 2009.; Milas, 2009.).

\footnotetext{
poduzeću, javnom ili privatnom sektoru), 4 - srednji menadžment (bilo u vlastitom ili tuđem poduzeću, javnom ili privatnom sektoru), 5 - službenici, 6 - kvalificirani radnici, uključujući i bolničke sestre, 7 - nekvalificirani i niskokvalificirani radnici, 8 - poljoprivrednici i ribari. Kategorije 1-3, 4-5 te 7-8 su međusobno spojene kako bi u regresijskoj analizi indikator mogao biti predstavljen s tri tzv. dummy varijable. Kategorija 6, najzastupljenija u uzorku, uzeta je kao referentna vrijednost.

14 Vidi: https://razvoj.gov.hr/o-ministarstvu/regionalni-razvoj/indeks-razvijenosti/112 (25. 2. 2016). Županijske vrijednosti indeksa razvijenosti dostupne su na stranici: https://razvoj.gov.hr/UserDocsImages/arhiva/Regionalni\%20razvoj/Vrijednosti\%20indeksa\%20razvijenosti\%20i\%20pokazatelja\%20za\%20izra\%C4\%8Dun\%20ind eksa\%20razvijenosti\%20na\%20\%C5\%BEupanijskoj\%20razini\%202013..pdf.

15 Više o metodologiji računanja ovog indeksa dostupno je na: http://www.konkurentnost.hr/Default.aspx?sec=93.

16 Usp. http://www.gemhrvatska.org/.
} 
U skladu s novijim spoznajama o indikatorima pristajanja strukturalnih modela (Byrne, 2009; Hair i sur., 2009.; Hu i Benter, 1999.), prihvaćanje konfirmacijskog modela egalitarnog sindroma temeljimo na sljedećim pokazateljima - izabranim prema Klinovim (2010.) preporukama:

(1) vrijednosti pokazatelja SMRM (standardizirani korijen iz prosjeka kvadratnih odstupanja varijanci i kovarijanci zadanih modelom u odnosu na empirijski dobivene), mjere apsolutnog pristajanja, trebaju biti jednake ili manje od 0,05;

(2) vrijednosti pokazatelja RMSEA (korijen iz prosječne kvadrirane pogreške aproksimacije), mjere parsimoničnosti, trebaju biti jednake ili manje od 0,05;

(3) vrijednosti pokazatelja CFI (usporedni indeks prikladnosti), mjere inkrementalnog pristajanja (model od interesa uspoređuje se s onim koji podrazumijeva nezavisnost latentnih varijabli), trebaju biti što bliže (ili veće od) 0,95.

Spolna i dobna invarijantnost modela egalitarnog sindroma ispitana je dvjema višeskupinskim konfirmacijskim analizama koje omogućuju usporedbu modela u kojem su odnosi među svim varijablama izjednačeni u obje skupine (muškarci/žene, odnosno mlađi/stariji sudionici) $s$ modelom koji te odnose određuje temeljem prikupljenih podataka. Za ispitivanje razlike između "fiksiranog" i "slobodnog" modela koristili smo Satorra-Bentlerov test statističke značajnosti razlika između vrijednosti hi-kvadrata i stupnjeva slobode ta dva modela.

U dijelu rada koji propituje kriterijsku valjanost skale egalitarnog sindroma, ispitali smo njezinu povezanost $\mathrm{s}$ indikatorom averzije spram rizika (Carter i Yeqing, 2005.) koristeći Pearsonovu korelaciju. Za testiranje hipoteze o perzistenciji egalitarnog sindroma rabili smo multivarijatnu linearnu regresijsku analizu, a za testiranje hipoteze o mogućim posljedicama egalitarnog sindroma korelacijsku analizu (Pearsonov i Spearmanov koeficijent).

8 Za provedbu statističkih postupaka rabili smo programske pakete IBM-SPSS 22 i AMOS 22.

\section{Rezultati}

\subsection{PROVJERA KONFIRMACIJSKOG MODELA EGALITARNOG SINDROMA}

Testiranje višerazinskog modela egalitarnog sindroma (usp. sliku 1), koji je uključio 27 čestica, rezultiralo je prihvatljivim pristajanjem modela A prikupljenim podacima (Hooper, Coughlan $\mathrm{i}$ Mullen, 2008.): $\chi^{2}(311)=1190$; SRMR $=0,05$; RMSEA $=0,05$ (90\% IP /interval pouzdanosti $/=0,05-$ 0,06 ); $\mathrm{CFI}=0,92$. U usporedbi s testiranjem istoga modela na studentskom uzorku (Štulhofer $\mathrm{i}$ Burić, 2015.), saturacije pet latentnih dimenzija nižega reda latentnom dimenzijom višega reda (egalitarni sindrom) razvidno su veće u ovom uzorku opće populacije i kreću se u rasponu od 0,75 do 0,98 . 


\section{SLIKA 1.}

Rezultati testiranja konfirmacijskog modela egalitarnog sindroma (model A)

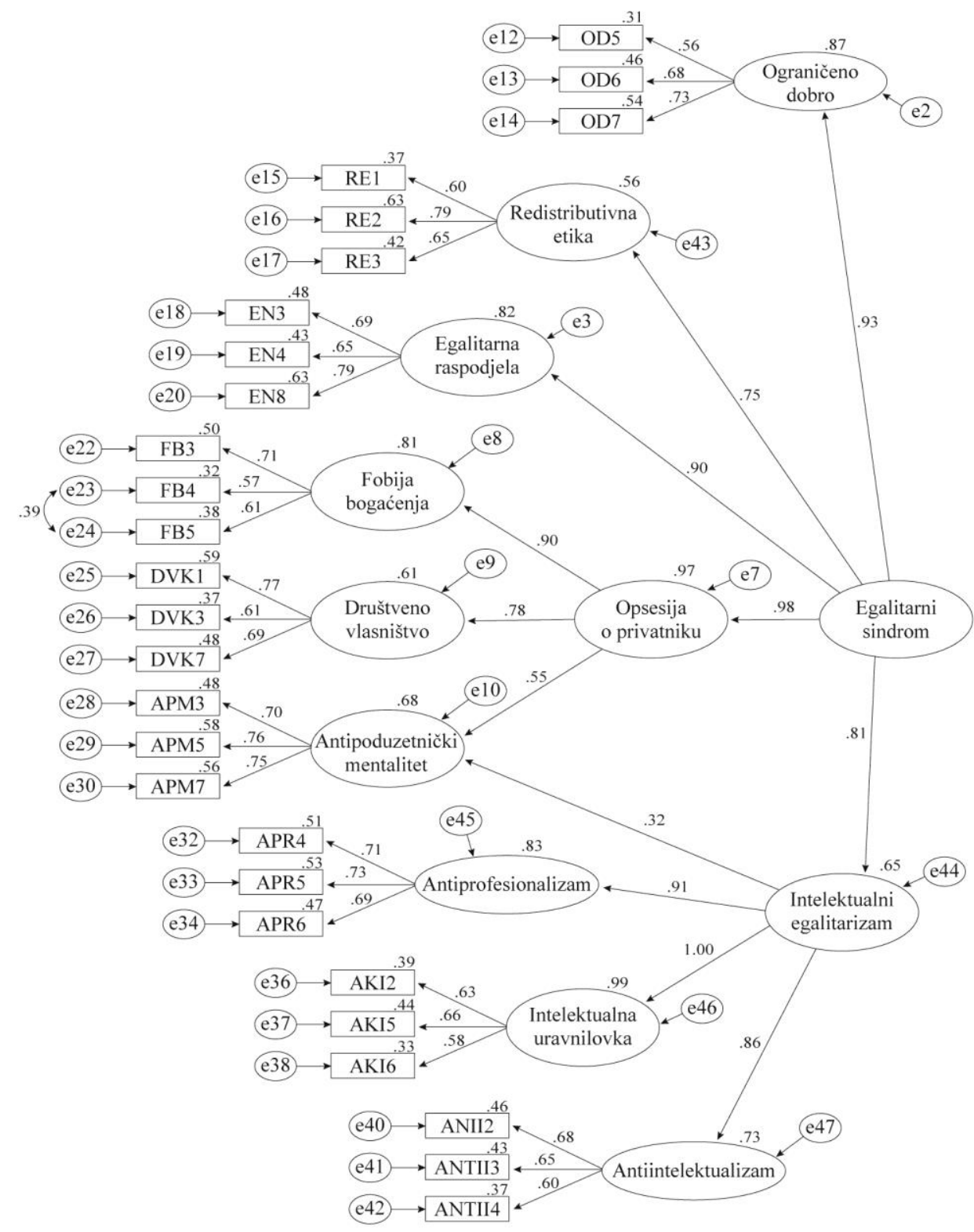

U cilju izrade što kraće skale egalitarnog sindroma, u sljedećem smo koraku testirali respecificirani model koji je uključio samo 15 čestica (slika 2). Kao i u prethodnom slučaju, testiranje ovog reduciranog modela (model B) egalitarnog sindroma ukazalo je na prihvatljivo pristajanje podacima: $\chi^{2}{ }_{(84)}=395$; SRMR $=0,04 ;$ RMSEA $=0,06(90 \%$ IP $=0,06-0,07) ;$ CFI $=0,94$. Valja primijetiti kako su saturacije dimenzija prvog reda latentnom dimenzijom drugog reda u modelu $\mathrm{B}$ podudarne onima u modelu $\mathrm{A}$. 


\section{SLIKA 2.}

Respecificirani model egalitarnog sindroma (model B)

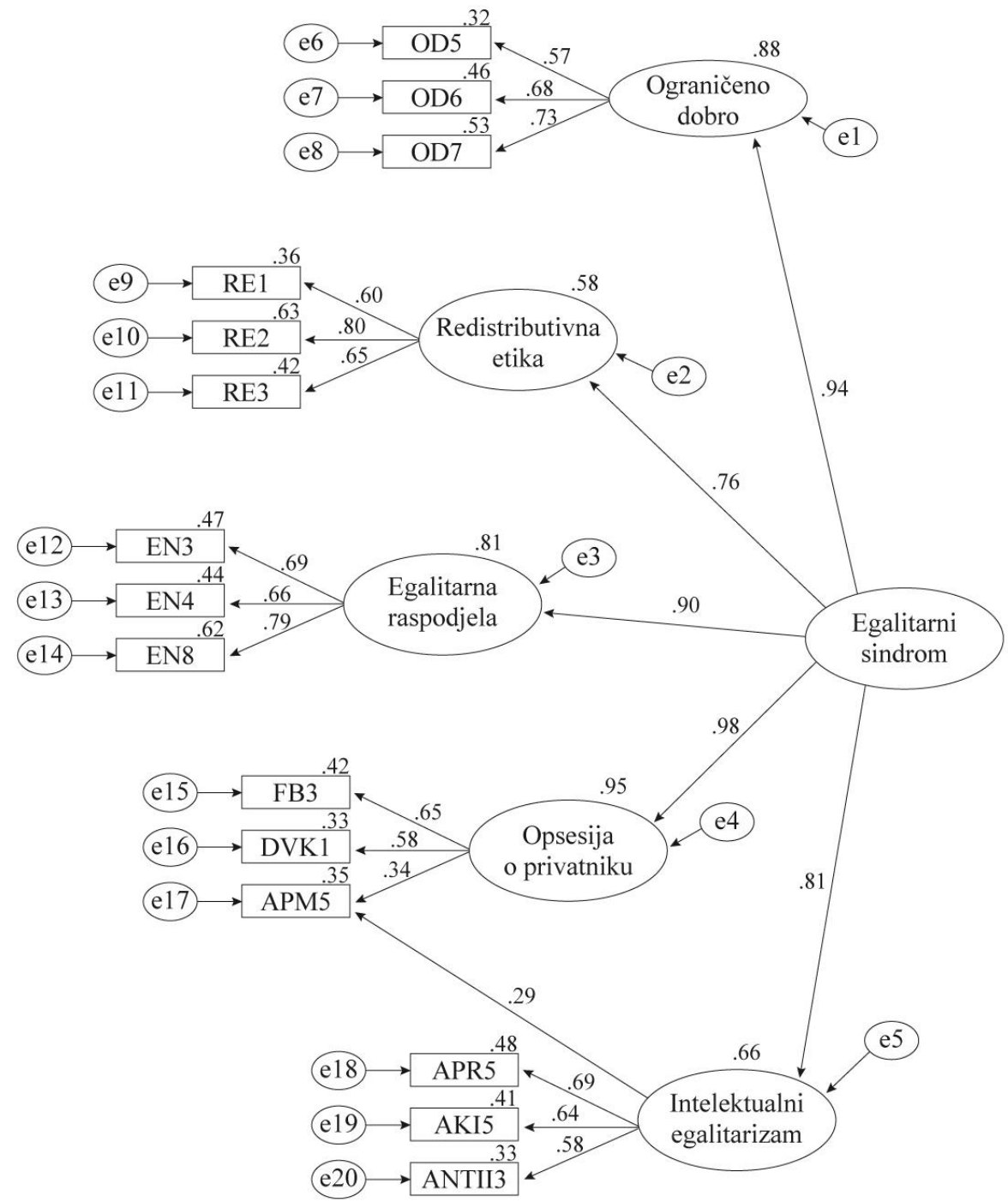

U narednom koraku, proveli smo dvije višeskupinske konfirmacijske analize modela B kako bismo ispitali njegovu spolnu i dobnu invarijantnost. Rečeno na drugi način, valjanost modela željeli smo testirati i kroz analizu mogućih spolnih i dobnih razlika u strukturnom (odnosi među latentnim dimenzijama) i/ili mjernom dijelu modela (saturiranost čestica faktorima prvog reda). Testiranje invarijantnosti modela prema spolu nije rezultiralo značajnom razlikom ni u mjernom $\left(\Delta \chi^{2}=6,3\right.$; $\Delta \mathrm{df}=11 ; p>0,85)$, niti u strukturnom dijelu reduciranog modela egalitarnog sindroma $\left(\Delta \chi^{2}=12,3\right.$; $\Delta \mathrm{df}=16 ; p>0,72)$.

U cilju analize dobne invarijantnosti, iz uzorka su izdvojene dvije skupine čija je socijalizacija bila vezana uz različite političko gospodarske sustave (socijalističko planski, odnosno demokratsko tržišni). U prvu su skupinu svrstane osobe stare 60 ili više godina, a u drugu oni rođeni nakon raspada socijalističkog sustava (1989.), to jest pojedinci u dobi do 27 godina. Kao i u prethodnom slučaju, analiza nije utvrdila statistički značajne razlike u mjernom $\left(\Delta \chi^{2}=9,9 ; \Delta \mathrm{df}=11 ; p>0,53\right)$, odnosno strukturnom dijelu modela $\left(\Delta \chi^{2}=16,1 ; \Delta \mathrm{df}=16 ; p>0,44\right)$ - potvrđujući da model podjednako dobro mjeri fenomen egalitarnog sindroma $u$ bitno različito socijaliziranim generacijama. 


\subsection{VALIDACIJA SKALE EGALITARNOG SINDROMA}

Konvergencijska valjanost Skale egalitarnog sindroma provjerena je ispitivanjem njezine povezanosti s teorijski srodnim konstruktom izbjegavanja rizika. Prvo smo formirali dvije skale egalitarnog sindroma - dužu s 27 (SEMA-27) i kraću s 15 čestica (SEMA-15) ${ }^{17}$ - zbrajanjem vrijednosti na česticama uključenim u model A, odnosno B. ${ }^{18}$ Kako bi teorijski raspon skala iznosio 1-5, sumirane smo vrijednosti podijelili s brojem obuhvaćenih čestica. Nakon toga smo testirali povezanost tako oblikovanih skala sa složenim indikatorom averzije spram rizika. Prema očekivanju, obje su skale (na kojima veći rezultat ukazuje na snažnije prihvaćanje egalitarnog sindroma) bile statistički značajno povezane $s$ izbjegavanjem rizika $\left(r_{\mathrm{SEMA}-27}=0,37, p<0,001 ; r_{\mathrm{SEMA}}\right.$ $15=0,35, p<0,001)$.

\subsection{RAŠIRENOST PRIHVAĆANJA VRIJEDNOSTI POVEZANIH S EGALITARNIM SINDROMOM}

Na razini čitavog uzorka, prosječna vrijednost na SEMA-27 iznosila je 3,87 (SD = 0,69; medijan = $3,89)$. Imajući u vidu kako teorijski raspon skale iznosi 1-5, pri čemu jedinica označava najvišu razinu odbacivanja, a petica najvišu razinu prihvaćanja vrijednosti egalitarnog sindroma, dobivena vrijednost govori o većinskom prihvaćanju egalitarnog sindroma. Nakon što smo iz računanja nacionalnog prosjeka izostavili ekstremne vrijednosti (jedinice i petice), rezultat je ostao gotovo nepromijenjen $(3,84)$. Gotovo jednu petinu $(18 \%)$ sudionika istraživanja karakterizirao je rezultat veći ili jednak jednoj standardnoj devijaciji iznad prosjeka, što smatramo snažnim prihvaćanjem vrijednosti egalitarnog sindroma.

Prosječni rezultat na pojedinim dimenzijama SEMA-27 varirao je u rasponu od 4,06 (SD =0,69) u slučaju opsesije o privatniku do 3,68 (SD = 0,95) u slučaju perspektive ograničenog dobra. Opsesija o privatniku, norma egalitarne raspodjele $(M=3,97 ; S D=0,98)$ i intelektualni egalitarizam $(M=$ 3,$74 ; \mathrm{SD}=0,76$ ) tri su najprihvaćenije dimenzije.

Kada je riječ o županijskim prosjecima, najveće su vrijednosti zabilježene u Brodsko-posavskoj $(4,60)$, Ličko-senjskoj $(4,56)$ i Bjelovarsko-bilogorskoj $(4,38)$ županiji. Tri županije obilježene najmanjim prihvaćanjem egalitarnog sindroma bile su Međimurska $(3,45)$, Istarska $(3,61)$ i Sisačko-moslavačka $(3,64)$ županija. ${ }^{19}$

\subsection{TESTIRANJE HIPOTEZE O PERZISTENCIJI EGALITARNOG SINDROMA}

$\mathrm{Na}$ bivarijatnoj razini, testiranje teze o perzistiranju egalitarnog sindroma rezultiralo je niskom, ali značajnom povezanosti između vrijednosti SEMA-27 i dobi $(r=0,12 ; p<0,001)$ - i to u očekivanom smjeru. Kako bismo provjerili mogući utjecaj drugih, srodnih obilježja na prikazane rezultate bivarijatnih analiza, u sljedećem koraku proveli smo multivarijatnu regresijsku analizu sa SEMA-27 kao zavisnom varijablom (tablica 1). Kao nezavisne varijable u model su uvršteni indiktori spola, dobi, prebivališta (urbano vs. ruralno), obrazovanja, osobnih prihoda te indikatori zanimanja, odnosno profesionalnog statusa. S obzirom da je riječ o trenutnom zanimanju, posljednji je indikator smanjio veličinu uzorka jer su iz analize izostavljeni učenici, nezaposlene osobe i umirovljenici. Želeći provjeriti mogućnost neizravnog utjecaja dobi na zavisnu varijablu, provjerili

\footnotetext{
17 Za popis čestica koje sačinjavaju SEMA-27 i SEMA-15 usp. prilog u Štulhofer i Burić (2015.).

18 Imajući u vidu kako je riječ o ugniježđenim mjerama, visoka je korelacija između duže i kraće verzije SEMA $(r=0,97)$ očekivana.

19 Valja podsjetiti kako županijski poduzorci nisu reprezentativni.
} 
smo i moderacijski utjecaj dobi, linearni i kvadratni, na odnos između obrazovanja i SEMA-27 (nije prikazano u tablici). Taj je postupak zahtijevao uključivanje umnoška varijabli dob i obrazovanja prethodno centriranih oko njihova prosjeka.

\section{TABLICA 1.}

Sociodemografski prediktori prihvaćanja egalitarnog sindroma (zavisna varijabla = SEMA-27)

\begin{tabular}{lc} 
& $\mathbf{N}=\mathbf{6 6 2}$ \\
\hline & $B / \beta$ \\
& S.E. $^{\mathrm{a}}$ \\
\hline \multirow{2}{*}{ Spol } & $-0,01 /-0,01$ \\
Dob & $(0,05)$ \\
& $0,00 / 0,03$ \\
& $(0,00)$ \\
\hline
\end{tabular}

Prebivalište

\begin{tabular}{|c|c|}
\hline Ruralno prebivalište (referentna vrijednost) & / \\
\hline Urbano prebivalište & $\begin{array}{c}-0.13 /-0,10^{*} \\
(0,05)\end{array}$ \\
\hline \multicolumn{2}{|l|}{ Obrazovanje } \\
\hline 1. tercil (najmanje obrazovani; referentna vrijednost) & / \\
\hline 2. tercil & $\begin{array}{c}-0,21 /-0,16^{*} \\
(0,09)\end{array}$ \\
\hline 3. tercil (najviše obrazovani) & $\begin{array}{c}-0,26 /-0,15^{*} \\
(0,12)\end{array}$ \\
\hline
\end{tabular}

1. kvartil (najniži prihodi; referentna vrijednost)

2. kvartil

3. kvartil

4. kvartil (najviši prihodi)

Zanimanje

Stručnjaci i viši menadžment

Srednji menadžment i službenici

KV radnici (referentna vrijednost)

NKV radnici i poljoprivrednici

$R^{2}$

a S.E. = standardna pogreška mjerenja.

${ }^{*} p<0,05 ;{ }^{* *} p<0,01$; ** $p<0,001$.

Kao što prikazuje tablica 1 , spol, dob i osobni prihodi nisu se pokazali značajno povezani $\mathrm{s}$ egalitarnim sindromom. Za razliku od njih, obrazovanje i urbano prebivalište bili su značajno i negativno povezani s kriterijem. Značajnim se prediktorom pokazao i profesionalni status, pri čemu su stručnjaci, viši srednji menadžeri te službenici iskazali značajno manju razinu egalitarnog
$-0,07 /-0,05$

$(0,08)$

$-0,10 /-0,07$

$(0,08)$

$-0,08 /-0,05$

$(0,09)$

$-0,46 /-0,19^{* * *}$

$(0,12)$

$-0,19 /-0,11^{*}$

$(0,07)$

$0,05 / 0,03$

$(0,09)$

0,13 
sindroma u odnosu na KV radnike. Veličina svih povezanosti je mala $(\beta=-0,10--0,19)$, a regresijski je model protumačio tek $13 \%$ varijance egalitarnog sindroma.

Kako bi utvrdili je li odnos između dobi i egalitarnosti diskontinuiran (što prethodna analiza nije mogla detektirati), dodatna je provjera provedena multivarijatnom logističkom regresijskom analizom u kojoj je zavisna varijabla bila pripadnost dobnoj skupini koja nije bila socijalizirana u starom režimu (15-30 godina), u odnosu na onu koja jest (60 i više godina). Zanimanje, prebivalište, obrazovanje, prihodi i SEMA-27 uvršteni su u model kao nezavisne varijable. Potvrđujući robusnost prethodnih nalaza, niti ova analiza nije rezultirala značajnom vezom između prihvaćanja egalitarnog sindroma i pripadnosti različito socijaliziranim dobnim skupinama $(p>0,08)$.

\subsection{TESTIRANJE HIPOTEZE O MOGUĆIM POSLJEDICAMA KULTURNE INERCIJE}

Testirajući hipotezu o negativnom utjecaju egalitarnog sindroma na društveni i gospodarski razvoj županija, proveli smo analizu povezanosti između županijskog prosjeka na SEMA-27 i nekoliko indikatora županijskog razvoja: BDP per capita (2013.), dinamike BDP-a u razdoblju 2000.-2013., indeksa razvijenosti, indeksa konkurentnosti županija te vrijednosti TEA indeksa u 2014. i 2015. godini. Imajući u vidu socioekonomske specifičnosti glavnoga grada, analiza je provedena na uzorku županija sa i bez grada Zagreba.

\section{TABLICA 2.}

Povezanost između rezultata na skali egalitarnog sindroma (SEMA-27) i indikatora županijskog razvoja

\begin{tabular}{|c|c|c|c|c|c|c|c|}
\hline & SEMA-27 & (A) & (B) & (C) & (D) & (E) & (F) \\
\hline & \multicolumn{7}{|c|}{$\begin{array}{c}r \text { bez grada Zagreba } \\
\text { ( } r \text { s uključenim Zagrebom) }\end{array}$} \\
\hline SEMA-27 & 1 & $\begin{array}{c}-0,34 \\
(-0,30)\end{array}$ & $\begin{array}{c}0,39 \\
(0,34)\end{array}$ & $\begin{array}{c}-0,27 \\
(-0,11)\end{array}$ & $\begin{array}{c}-0,19 \\
(-0,14)\end{array}$ & $\begin{array}{c}-0,31 \\
(-0,31)\end{array}$ & $\begin{array}{c}-0,36 \\
(-0,34)\end{array}$ \\
\hline $\begin{array}{l}\text { (A) Indeks županijske razvijenosti } \\
\text { (2013.) }\end{array}$ & & 1 & $\begin{array}{c}-0,79 \\
(-0,82)\end{array}$ & $\begin{array}{c}0,65 \\
(0,67)\end{array}$ & $\begin{array}{c}0,84 \\
(0,86)\end{array}$ & $\begin{array}{c}0,31 \\
(0,31)\end{array}$ & $\begin{array}{c}0,43 \\
(0,43)\end{array}$ \\
\hline $\begin{array}{l}\text { (B) Županijska konkurentnost } \\
\text { (rang; 2013.)* }\end{array}$ & & & 1 & $\begin{array}{c}-0,66 \\
(-0,70)\end{array}$ & $\begin{array}{c}-0,67 \\
(-0,74)\end{array}$ & $\begin{array}{c}-0,59 \\
(-0,58)\end{array}$ & $\begin{array}{c}-0,36 \\
(-0,39)\end{array}$ \\
\hline (C) Županijski BDP (2013.) & & & & 1 & $\begin{array}{c}0,63 \\
(0,85)\end{array}$ & $\begin{array}{c}0,19 \\
(0,15)\end{array}$ & $\begin{array}{c}0,41 \\
(0,25)\end{array}$ \\
\hline $\begin{array}{l}\text { (D) Promjene u županijskom BDP- } \\
\text { u (2000.-2013.) }\end{array}$ & & & & & 1 & $\begin{array}{c}0,18 \\
(0,27)\end{array}$ & $\begin{array}{c}0,09 \\
(0,35)\end{array}$ \\
\hline (E) TEA ${ }^{a}(2014)$. & & & & & & 1 & $\begin{array}{c}0,34 \\
(0,35)\end{array}$ \\
\hline
\end{tabular}

(F) TEAa (2015.)

Bilješka: kako je riječ o populacijskoj analizi, p vrijednosti su izostavljene iz prikaza.

a Indeks rane poduzetničke aktivnosti.

* Spearmanov koeficijent rang korelacije; ostale brojke prikazuju koeficijente Pearsonove korelacije.

Kao što prikazuje tablica 2, prihvaćanje egalitarnog sindroma značajno je i negativno povezano $\mathrm{S}$ indikatorima županijske razvijenosti. Veći rezultati na SEMA-27 odgovaraju nižim vrijednostima županijskog razvoja i nižim rangom konkurentnosti, nižim BDP-om i slabijim rastom BDP-a tijekom razdoblja 2000.-2013. te nižom razinom rane poduzetničke aktivnosti (TEA) u obje godine mjerenja (2014. i 2015.). U cjelini, veličine su utvrđenih povezanosti varirale u rasponu od malih 
do umjerenih. Kako bismo omogućili detaljniji uvid u opisane povezanosti, analizirali smo povezanost indeksa županijskog razvoja, konkurentnosti te rane poduzetničke aktivnosti (2015.) s pet dimenzija empirijski revidiranog egalitarnog sindroma. U sva tri slučaja, najveća je povezanost s navedenim pokazateljima županijske razvijenosti zabilježena na dimenzijama opsesija o privatniku $(r=-0,39-0,62)$, norma egalitarne raspodjele $(r=-0,41--0,50)$ te intelektualni egalitarizam $(r=0,24-0,26)$.

\section{DISKUSIJA}

Kao i u slučaju testiranja na studentskom uzorku (Štulhofer i Burić, 2015.) i ovo je istraživanje potvrdilo pristajanje oba testirana modela egalitarnog sindroma prikupljenim podacima. Time smo potvrdili realističnost Županovljeve teorijske koncepcije prema kojoj je egalitarni sindrom višedimenzionalni sociokulturni fenomen. Također, utvrdili smo spolnu i dobnu invarijantnost obje verzije skale egalitarnog sindroma (SEMA-27 i SEMA-15) te potvrdili njihovu konvergencijsku valjanost.

Provedene analize nude barem dva važna uvida. Prvo, prosječni rezultat na SEMA-27 u nacionalnom uzorku korištenom u ovoj studiji nalazi se u zoni izraženog prihvaćanja egalitarizma. Drugo, generacijska pripadnost nije značajan prediktor vrijednosti egalitarnog sindroma, već su to obilježja poput veličine prebivališta, obrazovanja i profesionalnog statusa. Imajući u vidu da je Županov smatrao kako klicu egalitarnog sindroma valja tražiti u agrarnim društvima koje karakterizira materijalna oskudica te niska razina modernizacije (Županov, 1970.; 1977.), navedene prediktore egalitarnog sindroma možemo promatrati kao strukturalna obilježja koja označavaju stupanj udaljenosti od tradicionalne agrarne zajednice. U tom smislu, jedan od idućih koraka u analizi kulturalne inercije valjalo bi usmjeriti upravo prema društvenim kategorijama među kojima je prihvaćanje vrijednosti egalitarnog sindroma najizraženije. U cilju potpunijeg razumijevanja egalitarnog sindroma, upravo bi među tim društvenim skupinama valjalo detaljnije ispitati jesu li, i na koji način, tranzicijski procesi i posttranzicijska stvarnost revitalizirali egalitarni sindrom ${ }^{20}$. Ako raširenost egalitarnog sindroma negativno utječe na socioekonomski razvoj, za pretpostaviti je kako će razvojno zaostajanje povratno utjecati na intenziviranje sindroma poglavito u najpogođenijim društvenim slojevima.

S obzirom na ishode testiranja obje postavljene hipoteze, možemo konstatirati kako rezultati istraživanja govore u prilog Županovljevoj tezi o perzistenciji egalitarnog sindroma te ukazuju na sustavnu negativnu povezanost između prihvaćanja vrijednosti povezanih $\mathrm{s}$ egalitarnim sindromom i indikatora socioekonomskog razvoja. Valja uočiti kako nepovezanost dobi i SEMA-27, kontrolira li se prinos drugih relevantnih obilježja, ne opovrgava hipotezu o kulturalnoj inerciji. Naprotiv, činjenica da je prihvaćanje vrijednosti povezanih s egalitarnim sindromom podjednako prisutno u različitim generacijama, odnosno da su razlike u prihvaćanju primarno vezane uz (dobrim dijelom transgeneracijske) efekte obrazovanja, socijalizaciju u manjim i tradicionalnijim zajednicama te profesionalnu socijalizaciju ${ }^{21}$, posve je suglasna ideji perzistencije egalitarnog sindroma. Moguće je, naime, da su društvene i gospodarske promjene tijekom 1990.-tih različito utjecale na intenzitet pristajanja uz egalitarističkih vrijednosti u pojedinim generacijama, brišući

\footnotetext{
${ }^{20} \mathrm{Na}$ ovaj smjer istraživanja upućuje i Županov kada ukazuje na mogućnost radikalizacije egalitarnog sindroma u razdoblju gospodarske stagnacije (Županov, 1983:60).

${ }^{21}$ Zbog nedostatka odgovarajućih indikatora, u okviru ovoga istraživanja nije moguće odgovoriti na pitanje je li ovdje doista riječ o efektu profesionalne socijalizacije u užem smislu ili, zapravo, efektu klasne socijalizacije (habitus).
} 
očekivane razlike između mlađih i starijih kohorti. Prihvaćanje egalitarnog sindroma moglo je tako rasti među mlađim generacijama (kao reakcija na rastuću nesigurnost i razglašene nepravilnosti u procesu pretvorbe i privatizacije), a istodobno se smanjivati među starijim, u socijalizmu odraslim, generacijama (kao nastojanje da se odbace proskribirane socijalističke i prihvate nove, tržišne vrijednosti).

Premda na prvi pogled problematična, činjenica kako su sociodemografska obilježja sudionika istraživanja rastumačila tek nešto više od desetine varijance prihvaćanja egalitararnog sindroma u skladu je s tezom kako je riječ o kulturološkom fenomenu koji nije u potpunosti moguće objasniti pojedinačnim iskustvima ili interesima. ${ }^{22}$ Egalitarni sindrom, kao što ga Županov opisuje, primarno je kolektivno obilježje ili, suvremenijim jezikom rečeno, vrijednosni sklop generiran strukturnim obilježjima svojstvenim hrvatskom društvu na nižoj razini modernizacijskog razvoja. Prema Županovu, utjecaj tih strukturnih obilježja (poput udjela poljoprivrednog stanovništva, obrazovne strukture te stupnja urbanizacije) na sociokulturno profiliranje društva i dalje je aktualan. U tom smislu, strukturalne bi osobitosti lokalne zajednice mogli biti bolji prediktori prihvaćanja egalitarnog sindroma od individualnih obilježja.

Županovljevu središnju tezu o egalitarnom sindromu kao sociokulturnoj kočnici razvoja preliminarno podupiru rezultati testiranja hipoteze o mogućim posljedicama kulturne inercije, prema kojem je županijska razvijenost u negativnom odnosu spram prihvaćanja vrijednosti povezanih s egalitarnim sindromom. Ti rezultati sugeriraju plodnost pristupa razvojnim prijeporima koji obilježavaju suvremeno hrvatsko društvo iz perspektive TES-a. Primjerice, problematiziranje odnosa između prihvaćanja egalitarističkih vrijednosti i trenutne razine društvene razvijenosti i konkurentnosti bilo bi teško izvedivo bez refleksija na opsesiju o privatniku. U konstelaciji okolnosti u kojima se trenutno nalazi hrvatsko društvo, a koje nalažu postizanje znatno viših stopa ekonomskog rasta, održavanje opsesije o privatniku itekako će opterećivati razvoj poduzetništva, a time i ostvarivanje razvojnih imperativa. Da Hrvatska i danas ima problema s otporom poduzetništvu implicitno potvrđuju i rezultati nekih drugih istraživanja. Prema GEM istraživanju iz 2015., Hrvatska se prema percepciji društvenog statusa poduzetnika nalazi na 54. mjestu od 60. zemalja u kojima se istraživanje redovito provodi (Singer i sur., 2016.). Indikativan je i zaključak analize GEM istraživanja provedenih u razdoblju 2002.-2011., prema kojem po svim pokazateljima poduzetničke aktivnosti Hrvatska zaostaje za zemljama čijoj razvojnoj skupini pripada. Na tragu navedenog možemo promatrati i podatak iz istraživanja Eurobarometar 84, provedenog u jesen 2015., prema kojem se za poticanje privatnih ulaganja javnim novcem na razini EU-a zalaže natpolovična većina Europljana, ali ispodpolovična većina građana Hrvatske. ${ }^{23}$

Afirmacija hipoteze o mogućim posljedicama kulturne inercije aktualizira i one komponente egalitarnog sindroma koje smo povezali s dimenzijom intelektualnog egalitarizma (antikreativnost, antiintelektualizam i antiprofesionalizam). U članku Egalitarizam i industrijalizam (Županov, 1970.; 1977.), Županov posvećuje priličnu pozornost niskoj razini onodobne društvene inovativnosti i kreativnosti koje vidi čimbenicima društvene neučinkovitosti. Uvidi o nacionalnoj inovativnosti i kreativnosti niti početkom 21. stoljeća nisu, čini se, značajno drukčiji. Prema

22 Ovaj uvid dugujemo anonimnom recenzentu.

${ }^{23}$ Vidi: http://ec.europa.eu/croatia/news/docs/2016/20160229_eb-84-nr-croatia.pdf (29. 2. 2016). 
istraživanju globalne inovativnosti iz 2015., Hrvatska se na listi koja obuhvaća 141 državu nalazi na 40. mjestu, iza svih zemalja Zapadne Europe kao i brojnih zemalja Istočne Europe ${ }^{24}$.

\subsection{PitANJE SMJERA POVEZANOSTI}

Promatrano strogo metodološki, naši podaci ne potvrđuju, već samo ne odbacuju hipotezu o perzistenciji. Potvrda bi hipoteze, primjerice, zahtijevala usporedbu s podacima prikupljenim tijekom socijalizma, no takvih podataka nema (Bernik, 1990.). U tom smislu, predstavljene je nalaze moguće tumačiti na dva načina. Prema prvom, oni ukazuju na perzistenciju egalitarnog sindroma, što znači da su vrijednosti koje opisuju taj pogled na svijet jedan od mogućih uzroka usporenom razvoju. Druga, alternativna interpretacija naših rezultata egalitarni sindrom vidi posljedicom (a ne uzorkom) razvojnih poteškoća - poglavito onih vezanih uz rat i tranzicijske troškove tijekom 1990.-tih godina. Premda su oba tumačenja usuglasiva s našim nalazima, drugo bi tumačenje, želi li biti uvjerljivo, moralo objasniti kako je moguće da su različiti modeli razvoja (različite inačice državno planskog i tržišnog sustava), prisutni u posljednjih pedesetak i više godina, rezultirali manje-više identičnom kutijom sociokulturnih alata za snalaženje u svakodnevnom životu (v. Swidler, 1986.)? Rečeno na drugi način, argumentacija teze prema kojoj je neadekvatni socioekonomski razvoj uzrok egalitarnog sindroma, a ne obrnuto, zahtijeva demonstraciju supstancijalnih sličnosti, odnosno velikog preklapanja, između tih gospodarskih modela u hrvatskoj praksi.

Autori rada skloni su specifičnoj kombinaciji gore navedenih tumačenja. Premda za hipotetski scenarij koji slijedi nemamo empirijskih argumenata, vjerujemo kako je riječ o plauzibilnoj i do određene mjere provjerljivoj naraciji - primarno kroz retrospektivnu analizu reakcije na troškove post-socijalističke tranzicije (Štulhofer, 2000.). Egalitarni sindrom, kao naslijeđe predmodernih agrarnih zajednica (Županov, 1970.), socijalizam je ustoličio kao dominantnu društvenu vrijednost, dijelom kroz proklamirane moralne vrijednosti (jednakost svih) i kritiku buržujskog elitizma i meritokracije, a dijelom nastojanjem političke elite da eliminira svaku konkurenciju. ${ }^{25} \mathrm{U}$ tom i takvom kontekstu, prihvaćanje je egalitarnog sindroma bilo funkcionalno, odnosno te su vrijednosti bile egzistencijalno koristan alat (usp. Swidler, 1986.). Raspadom socijalizma i transformacijom hrvatskog društva u demokratski i tržišno orijentirani sustav, prihvaćanje je vrijednosti vezanih uz egalitarni sindrom trebalo slabjeti. U promijenjenim društvenim uvjetima, stare vrijednosti više nisu bile u stanju efikasno usmjeravati svakodnevnu aktivnost. Promijenjena su pravila igre zahtijevala novi pogled na svijet i nove vrijednosti, odnosno nove kulturalne alate. No, prije no što su ti novi alati mogli zaživjeti, visoki tranzicijski troškovi (čemu su pridonijela i ratna razaranja i žrtve), raširena percepcija korumpiranosti procesa pretvorbe i privatizacije, sveprisutni utjecaj klika i nepotističkih veza te perpetuiranje političkog patronata nad javnim resursima i gospodarskim aktivnostima kroz instituciju stranačke podobnosti potaknuli su povratak starom pogledu na svijet.26 Umjesto prihvaćanja i razrade novih, vratili smo se starim, dobro poznatim alatima. ${ }^{27}$ Prihvaćanje egalitarnog sindroma zabilježeno u ovoj studiji moglo bi,

\footnotetext{
24 Vidi: https://www.globalinnovationindex.org/userfiles/file/reportpdf/gii-full-report-2015-v6.pdf (1. 3. 2016.).

25 Primjerice, optužba za "tehnokratizam" najčešće se koristila protiv neovisnih stručnjaka i intelektualaca.

${ }^{26}$ Nedavni rad Nistotskaye, Charrona i Lapuentea (2015.) donosi empirijski uvjerljiv primjer odnosa između institucionalnog okvira (mjerenog percepcijom kvalitete upravljanja) i poduzetničke aktivnosti u malim i srednjim poduzećima u 172 regije EU-a.

${ }^{27}$ Ovdje se približavamo Sztompkinom određenju tzv. civilizacijske nekompetentnosti (Sztompka, 2000.). Sintagma označava niz sociokulturnih barijera koje usporavaju adaptaciju građana bivših socijalističkih zemalja na nove
} 
dakle, biti istodobno i uzrok i posljedica naših razvojnih problema. No, bez obzira koji je od dva scenarija točniji, oba potvrđuju aktualnost Županovljevog inzistiranja na povezanosti između društvenog razvoja i kulture.

\subsection{OGRANIČENJA STUDIJE}

Uz prednosti, poput probabilističkog uzorka koji omogućuje generalizaciju nalaza te ekstenzivnu validaciju novog instrumenta, naše istraživanje uključuje i nekoliko ograničenja. Prva od njih je presječni karakter studije, koji onemogućuje analizu kauzalnosti. Usporedba dobnih skupina u našoj studiji, za razliku od dinamičke usporedbe dobnih kohorti (na temelju ponovljenih presječnih studija) ili longitudinalnog praćenja promjena na istom uzorku (panel studija), ne dozvoljava razlikovanje utjecaja dobi, odnosno starenja, od utjecaja specifične generacijske kulture i kulturnih promjena u okolini.

Drugo, naša analiza ne uzima u obzir društveni kontekst u kojem pojedinci djeluju. Kao što je već spomenuto, obilježja lokalnih zajednica i društvenih skupina mogla bi biti snažnije povezana s prihvaćanjem egalitarnog sindroma od individualnih obilježja. Empirijski rečeno, trebalo bi ispitati u kojoj mjeri obilježja lokalne sredine (npr. udio poljoprivrednog stanovništva, udio visokoobrazovanih, stupanj urbanizacije te društvena mobilnost), u odnosu na individualna obilježja sudionika, predviđaju prihvaćanje egalitarnog sindroma. Višerazinsko regresijsko modeliranje pristup je koji može odgovoriti na to pitanje.

Treće važno ograničenje odnosi se na analizu povezanosti između prihvaćanja egalitarnog sindroma i regionalne razvijenosti. Uz mali broj sudionika u većini županija i, posljedično, upitnu robusnost procjena na županijskoj razini, na pouzdanost analize utjecala je i činjenica kako se reprezentativnost korištenog uzorka odnosi isključivo na nacionalnu razinu.

Naposljetku, no nikako ne i najmanje važno, činjenica je da naša studija nije uključila konstrukte poput društvene solidarnosti, generaliziranog i institucionalnog povjerenja, poštivanja normi te suradljivosti, što je onemogućilo uvid u potencijalno važan odnos između prihvaćanja egalitarnog sindroma te uzajamnosti i spremnosti na suradnju.

\section{ZAKLJUČAK}

U prethodnome i ovome radu ponudili smo prvu cjelovitu operacionalizaciju Županovljeve teorije te argumentirali njezinu valjanost nizom analitičkih i statističkih postupaka. Rezultati naših analiza potvrđuju kreativnost i sociološku imaginaciju Josipa Županova, ali i empirijsku ukorijenjenost njegovih konceptualizacija. Premda metodološki ograničeni, nalazi o negativnoj vezi između prihvaćanja vrijednosti egalitarnog sindroma i razvojnih indikatora na županijskoj razini podupiru Županovljevu tezu o negativnoj ulozi egalitarnog sindroma. ${ }^{28}$ Smjer povezanosti, odnosno pitanje kauzalnosti, ostaje dakako otvoreno pitanje.

ekonomske i društvene okolnosti nastale urušavanjem socijalističkih sustava. Taj svojevrsni "kulturni zid", izgrađen i internaliziran tijekom socijalizma, sadrži pravila, norme, vrijednosti, navike i simbole koji su većim dijelom nefunkcionalni u post-socijalističkom okruženju.

${ }^{28}$ Analiza povezanosti između županijskih indikatora i pojedinačnih dimenzija egalitarnog sindroma pokazala je kako su opsesija o privatniku (negativan stav o poduzetništvu), norma egalitarne raspodjele (težnja za središnjom regulacijom razlika u plaćama), te intelektualna uravnilovka (otpor inovacijama i kreativnim rješenjima) najsnažnije povezane sa županijskim razvojem. 
Umjesto normativnog pristupa, koji prema našem mišljenju obilježava nedavnu kritiku TES-a (Dolenec, 2014.), vjerujemo u važnost istraživačkog pristupa Županovljevim tezama. Na budućim je istraživanjima, primjerice, utvrditi je li prihvaćanje egalitarnog sindroma sustavno povezano s razvojno problematičnim fenomenima, poput korupcije, kršenja normi ili uskog radijusa povjerenja (Dalhey, Newton i Welzel, 2011.), ili pak s razvojno poticajnim fenomenima kao što su suradljivost, generalizirano povjerenje, civilni angažman i poštivanje normi. Dvije predložene skale egalitarnog sindroma, SEMA-27 i SEMA-15 omogućuju rigoroznu analizu ishoda (perzistirajućeg) egalitarnog sindroma u suvremenom hrvatskom društvu. Premda držimo kako je SEMA-15, zbog svoje relativne kratkoće, upotrebljiva u širokom rasponu istraživanja društvenih fenomena, željeli bismo podsjetiti na korisnu i nedovoljno korištenu strategiju planiranih nedostajućih podataka (planned missing data). Riječ je o praksi koja omogućava smanjivanje broja čestica uključenih u upitnik (usp. Graham, 2009.), pri čemu se namjerno generirani nedostajući podaci jednostavno i statistički korektno imputiraju primjenom tzv. FIML (full information maximum likelihood) metode u nekom od programa za strukturalno modeliranje (Allison, 2003.; Arbucle, 2013.). Primjenom tzv. troformnog pristupa u planiranju nedostajućih podataka (Graham, Taylor, Olchowski i Allison, 2006.), korištenje SEMA-27 zahtijevalo bi uvrštavanje 21 čestice u upitnik, a u slučaju SEMA-15 samo 12.

Kao što smo već nagovijestili, željeli bismo predložiti tri široka istraživačka smjera u kojima bi uporaba predloženih skala egalitarnog sindroma mogla uroditi korisnim uvidima. Prijedlog temeljimo na našem uvjerenju da je TES između ostalog i primjer teorijskog konstrukta koji uspješno integrira dihotomiju struktura-djelovanje te da je kao takav primjenjiv u istraživanjima koje nastoje premostiti jaz između mikro i makro analitičke razine. Prvi istraživački smjer vezujemo uz analizu društvenog kapitala i socioekonomskog ponašanja, to jest uz ispitivanje povezanosti između egalitarnog sindroma te spremnosti na suradnju (ponad obiteljskog, odnosno rođačko poznaničkog kruga), generaliziranog povjerenja, civilnog angažmana, spremnosti na zaobilaženje normi i koruptivno djelovanje. Drugi smjer vezan je uz prostor politike i političke akcije, gdje bi naglasak mogao biti na propitkivanju odnosa između internalizacije egalitarnog sindroma i političkih preferencija, političkih ideologija, razumijevanja ideje društvene pravednosti, kriterija za procjenu dobrog upravljanja te sudjelovanja u različitim tipovima kolektivne akcije. Treći smjer odnosi se na gospodarsko djelovanje, poglavito poduzetničke aktivnosti. Mišljenja smo da bi valjalo detaljnije ispitati vezu između prihvaćanja egalitarističkih vrijednosti i sudjelovanja u gospodarskim aktivnostima te odnosa spram institucija tržišta.

Konačni odgovor na pitanje pomaže li nam Županovljeva teorija, razvijena prije više od četrdeset godina, razumjeti društveni razvoj u Hrvatskoj, nužno će biti empirijski u prvom, a teorijski u drugom koraku. Potvrde li buduća istraživanja sustavnu povezanost egalitarnog sindroma s nizom razvojno problematičnih fenomena, bit će potrebno pristupiti nadogradnji Županovljeve teorije. Poglavito kako bi pristupili rasvjetljavanju kauzalnih mehanizama u pozadini opaženih povezanosti (Hedström, 2005.) i tako se približili odgovoru na pitanje kako, ako uopće, egalitarni sindrom utječe na društveni razvoj. 


\section{REFERENCE}

1. Allison, P. D., 2003. Missing Data Techniques for Structural Equation Modeling. Journal of Abnormal Psychology, 112(4), str. 545-557. doi: 10.1037/0021-843X.112.4.545

2. Bernik, I., 1990. Functions of Egalitarianism in Yugoslav Society. Praxis International, 6(4), str. 425-432.

3. Byrne, B. M., 2010. Structural equation modeling with AMOS. New York: Taylor \& Francis.

4. Carter, A. M. i Yeqing, B., 2005. Exploring the Concept and Measurement of General Risk Aversion. Advances in Consumer Research, 32, str. 531-539.

5. Dalhey, J., Newton, K. i Welzel, C., 2011. How General is Trust in 'Most People'? Solving the Radius of Trust Problem. American Sociological Review, 76(5), str. 786-807. doi: 10.1177/0003122411420817

6. Dolenec, D., 2014. Preispitivanje "egalitarnog sindroma" Josipa Županova. Politička misao, 51(4), str. 41-64.

7. Dworkin, R., 1981a. What is Equality? Part 1: Equality of Welfare. Philosophy and Public Affairs, 10(3), str. 185-246.

8. Dworkin, R., 1981b. What is Equality? Part 2: Equality of Resources. Philosophy and Public Affairs, 10(4), str. 283-345.

9. Fanuko, N., 2011. Prirodni tokovi društva i uzbudljiva lakoća teorije. Revija za sociologiju, 36(34), str. 129-139.

10. Frankfurt, H. G., 2015. On Inequality. Princeton: Princeton University Press. doi: $10.1515 / 9781400873272$

11. Graham, J. W., 2009. Missing Data Analysis: Making It Work in the Real World. Annual Review of Psychology, 60, str. 549-576. doi: 10.1146/annurev.psych.58.110405.085530

12. Graham, J. W., Taylor, B. J. i Olchowski, A. E., 2006. Planned Missing Data Designs in Psychological Research. Psychological Methods, 11(4), str. 323-343. doi: 10.1037/1082989X.11.4.323

13. Hair, J. F. [et al.], 2009. Multivariate data analysis. New Jersey: Prentice Hall. Upper Saddle River.

14. Hedström, P., 2005. Dissecting the Social: On the Principles of Analytical Sociology. Cambridge: Cambridge University Press. doi: 10.1017/CB09780511488801

15. Hooper, D., Coughlan, J. i Mullen, M., 2008. Structural equation modelling: Guidelines for determining model fit. Electronic Journal of Business Research Methods, 6(1), str. 53-60.

16. Hu, L. i Bentler, P. M., 1999. Cutoff criteria for fit indexes in covariance structure analysis: Conventional criteria versus new alternatives. Structual Equation Modeling, 6(1), str. 1-55. doi: $10.1080 / 10705519909540118$

17. Kline, R. B., 2010. Principles and practice of structural equation modeling. New York: Guilford.

18. Lalić, D., 2005. Osobit potpis Josipa Županova kao istraživača suvremenog hrvatskog društva. Revija za sociologiju, 36(3-4), str. 141-148.

19. Milas, G., 2009. Istraživačke metode u psihologiji i drugim društvenim znanostima. Jastrebarsko: Slap.

20. Nistotskaya, M., Charron, N. i Lapuente, V., 2015. The wealth of regions: Quality of government and SMEs in 172 European regions. Environment and Planning C: Government and Policy, 33(5), str. 1125-1155. doi: 10.1177/0263774X15610058

21. Rawls, J., 1971. A Theory of Justice. Cambridge, MA: Harvard University Press.

22. Scanlon, T. M., 1996. The Diversity of Objections to Inequality: The Lindley Lecture. Lawrence, KS: University of Kansas.

23. Sekulić, D. i Šporer, Ž., 2005. Sociologija jednog života, život jedne sociologije. Ekonomski pregled, 56(3-4), str. 263-265.

24. Sen, A., 1992. Inequality Reexamined. New York: Russell Sage.

25. Singer, S. [et al.], 2016. Što čini Hrvatsku (ne)poduzetničkom zemljom? GEM Hrvatska 2012.2015. Zagreb: Centar za politiku razvoja malih i srednjih poduzeća i poduzetništva.

26. Štulhofer, A. i Burić, I., 2015. Je li egalitarni sindrom samo teorijska fantazija? Empirijski hommage Josipu Županovu. Politička misao, 52(3), str. 7-31. 
27. Štulhofer, A., 2000. Nevidljiva ruka tranzicije: ogledi iz ekonomske sociologije. Zagreb: Hrvatsko sociološko društvo.

28. Swidler, A., 1986. Culture in Action: Symbols and Strategies. American Sociological Review, 51(2), str. 273-286. doi: 10.2307/2095521

29. Sztompka, P., 2000. Civilisational competence: a prerequisite of postcommunist transition. Dostupno na: http://www.friends-partners.org/newfriends/audem/audem92/Sztompka.html.

30. Walzer, M., 1983. Spheres of Justice: A Defence of Pluralism and Equality. Oxford: Blackwell.

31. Zrinščak, S., 2002. Društveni razvoj u vrijednosnoj zamci. Sociologijski pogled na vrednote u hrvatskom društvu. Bogoslovska smotra, 71(2-3), str. 291-318.

32. Županov, J., 1970. Egalitarizam i industrijalizam. Naše teme, 14(2), str. 237-296.

33. Županov, J., 1977. Sociologija i samoupravljanje. Školska knjiga: Zagreb.

34. Županov, J., 1983. Marginalije o društvenoj krizi. Globus: Zagreb.

35. Županov, J., 1993. Dominantne vrijednosti hrvatskog društva. Erasmus, 2, str. 2-7.

36. Županov, J., 1995. Poslije potopa. Globus: Zagreb

37. Županov, J., 2002. Od komunističkog pakla do divljeg kapitalizma: odabrane rasprave i eseji. Zagreb: Hrvatska sveučilišna naklada.

38. Županov, J., 2011. Hrvatsko društvo danas - kontinuitet i promjena. Politička misao, 48(3), str. 145-163. 